\title{
Variation in the chemical composition of essential oils from Artemisia afra (Jacq) ex-Wild leaf obtained by different methods and the effect of oil extracts on Artemia salina $\mathbf{L}$
}

\section{Oluwagbenga $O$ Adeogun, Alfred Maroyi*, Anthony Jide Afolayan}

Medicinal Plants and Economic Development Research Centre, Department of Botany, University of Fort Hare, Alice, Eastern Cape, South Africa

*For correspondence: Email: amaroyi@ufh.ac.za

\begin{abstract}
Purpose: To determine the essential oils extracted from fresh and dried leaves of Artemisia afra using hydrodistillation (HD) and solvent free microwave extraction (SFME) methods and investigate the effects of the oils on Artemia salina.

Methods: The essential oils were obtained from fresh and dried leaves of Artemisia afra using hydrodistillation and solvent-free microwave extraction methods. The compounds present in the oils were analysed by gas chromatography-mass spectrometry (GC-MS). The oils were assayed for hatchability and lethality activities on Artemia salina for $72 \mathrm{~h}$. The lethal concentration $\left(L C_{50}\right)$ required to kill $50 \%$ of the population of brine shrimp by each test oil was determined using a Probit regression analysis.

Results: The most abundant compound was thujone (32.02 and $30.02 \%$ in fresh leaf by HD and SFME methods, respectively) and in dried leaf (26.57 and 25.82 \%, by HD and SFME methods, respectively). Mean hatchability success rate of all the oils was $70 \%$ while lethality activity was $30 \%$ after $72 \mathrm{~h}$ at the lowest concentration of the test oils. Half-maximal lethal concentration $\left(L C_{50}\right)$ on Artemia salina was 206.97 and $406.48 \mu \mathrm{g} / \mathrm{mL}$ of the oil from fresh leaf obtained by HD and SFME, respectively, while for the dried leaf, it was 277.18 and $669.30 \mu \mathrm{g} / \mathrm{mL}$ for the oil produced by HD and SFME, respectively.

Conclusion: The phytoconstituents in each oil varied based on the method of extraction and the state of the leaf before and after extraction. Furthermore, the toxic activity of the oils against Artemia salina suggests that they may possess anticancer properties but this needs to be further investigated.
\end{abstract}

Keywords: Artemia salina, Artemisia afra, Essential oils, hydrodistillation, Solvent-free microwave extraction, Hatchability, Lethality

This is an Open Access article that uses a funding model which does not charge readers or their institutions for access and distributed under the terms of the Creative Commons Attribution License (http://creativecommons.org/licenses/by/4.0) and the Budapest Open Access Initiative (http://www.budapestopenaccessinitiative.org/read), which permit unrestricted use, distribution, and reproduction in any medium, provided the original work is properly credited.

Tropical Journal of Pharmaceutical Research is indexed by Science Citation Index (SciSearch), Scopus, International Pharmaceutical Abstract, Chemical Abstracts, Embase, Index Copernicus, EBSCO, African Index Medicus, JournalSeek, Journal Citation Reports/Science Edition, Directory of Open Access Journals (DOAJ), African Journal Online, Bioline International, Open-J-Gate and Pharmacy Abstracts

\section{INTRODUCTION}

Artemisia Afra (Jacq) ex Wild, belongs to the Asteraceae family. It is known as Umhlonyane in isiXhosa, Mhlonyane in isiZulu, Lengana in
Tswana, Zengena in Southern Sotho and commonly addressed as African wormwood in English [1]. It is a medicinal plant commonly found in most part of eastern and southern Africa $[2,3]$. 
The plant has been documented to have significant importance in the treatment of colds, coughs, sore throat, pneumonia, poor appetite, diabetes, wound and malaria [4]. The plant can be applied to the preservation of food due to its antimicrobial properties [5]. The application of the plant to humans require screening for toxicity test. Some of the secondary metabolites from plants such as essential oil are regarded as being safe.

Several authors have reported that $\alpha$ - and $\beta$ thujone, camphor, borneal, 1,8-cineole, $Y$ terpinene, myrtenol and carvone are some essential oil constituents present in the leaf of $A$. afra [5-8]. It has been posited that oils ascribed natural aromatic fragrance to the leaf [5]. It has been documented that the composition of essential oils from the leaves of $A$. afra varied from one geographical zone to another with consideration to the time of harvest, of the plant [9].

Essential oils are derivatives of raw materials from plant origin. The oils consist of several compounds that are complex in nature and usually in liquid, but sometimes solid [10]. They are regarded as secondary metabolites that assist plants with self-defence against microbial attack [11]. The oils are predominantly extracted through hydrodistillation, steam distillation or organic solvent extractions(s) [12]. The use of steam and solvent distillation methods have resulted in the degradation and loss of several volatile compounds. This in addition to the extended time needed for distillation $[11,12]$. The use of hydrolytic processes to extract oil unsettle the unsaturated components of the oil and reduce the volatile compounds present in the oil [11].

The deficiency noticed with hydrolytic processes of extraction of essential oils raised the need for an alternative. The need for an alternative brings to fore the purpose of solvent-free microwave extraction (SFME) method for extraction of essential oils. SFME is based on the combination of microwave heating and distillation and is performed at atmospheric pressure. SFME is rapid in reaching the extraction temperature for the first essential oil droplet, high output of essential oil, lower energy requirement and high purity of the oil, these make it a desirable alternative. The method has been used successfully used to extract essential oils from several plants [13-15].

This study looked at the variation in the chemical compositions of essential oils generated through hydrodistillation and solvent-free microwave method using fresh and dried leaves of $A$. afra. The effects of each test essential oil on Artemia salina will be looked into. The need to investigate the toxicity of the oil on Artemia salina is due to the use of the plants by humans. Artemia salina toxicity bioassay is a preliminary method of screening plant constituents for cytotoxicity and hence for potential antitumor, anticancer and antimicrobial activities [16].

\section{EXPERIMENTAL}

\section{Plant material}

Fresh Artemisia afra leaves with were collected at Hogsback. The plant was authenticated and deposited at Griffen Herbarium, University of Fort Hare. The leaves were rinsed with distilled water. The samples were divided into two with one used immediately for analysis while the other was dried in an oven before analysis.

\section{Dry weight of the dried leaf}

The fresh leaves of Artemisia afra were placed in an oven at $25{ }^{\circ} \mathrm{C}$ for $48 \mathrm{~h}$ to determine the dry weight. The dry weight of the leaves of $A$. afra was deduced after the evaporation of moisture from the fresh leaves of the plant. This was calculated by subtracting the weight of the leaves after drying from the weight of the fresh leaves and then measured in percent.

\section{Determination of essential oil yield}

The yields of the essential oils were obtained through the deduction of the weight of essential oil, dried over anhydrous sodium sulfate from the weight of the leaves prior to extraction.

\section{Solvent-free microwave extraction (SFME) of the essential oils of $A$. afra leaves}

Solvent-free microwave extraction was carried out with a Milestone DryDIST (2004) apparatus. The multimode reactor has a twin magnetron $(2 \mathrm{x}$ $800 \mathrm{~W}, 2450 \mathrm{MHz}$ ) with a maximum delivered power of $500 \mathrm{~W}$ in $5 \mathrm{~W}$ increments. A rotating microwave diffuser ensures homogeneous microwave distribution throughout the plasma coated polytetrafluoroethylene (PTFE) cavity. The temperature was monitored by an external infrared sensor. Constant conditions of temperature and water were guaranteed by the reflux of condensed water, which was achieved by a circulating cooling system at $5{ }^{\circ} \mathrm{C}$. Two hundred grams of fresh and dried leaves respectively, were placed at different times into the reactor without addition of water or any 
solvent. The exhaustive extraction of the essential oils was obtained at $40 \mathrm{~min}$.

\section{Hydrodistillation}

Two hundred grams each of fresh and dried $A$. afra on different occasions were hydrodistilled for $3 \mathrm{~h}$ in an all-glass Clevenger apparatus in accordance with the method by of Okoh et al [1718]. The essential oils was collected and analyzed immediately.

\section{Gas chromatography-mass spectrometry (GC-MS)}

The Agilent $6890 \mathrm{GC}$ was coupled to an Agilent 5975 MSD with a Zebron-5MS column (ZB- 5MS $30 \mathrm{~m} \quad \mathrm{x} \quad 0.25 \mathrm{~mm} \quad \mathrm{x} \quad 0.25 \quad \mu \mathrm{m}) \quad(5 \%-$ phenylmethylpolysiloxane). GC grade helium was used as a carrier gas at a flow rate of 2 $\mathrm{mL} / \mathrm{min}$; splitless $1 \mu \mathrm{L}$ injections was used. Injector temp $280{ }^{\circ} \mathrm{C}$; source temperature 280 ${ }^{\circ} \mathrm{C}$. Oven temperature was $70 n^{\circ} \mathrm{C}$, ramped at 15 ${ }^{\circ} \mathrm{C} / \mathrm{min}$ to $120^{\circ} \mathrm{C}$, ramped at $10^{\circ} \mathrm{C} / \mathrm{min}$ to $180{ }^{\circ} \mathrm{C}$ then further ramped at $20{ }^{\circ} \mathrm{C} / \mathrm{min}$ to $270{ }^{\circ} \mathrm{C}$ and held for $3 \mathrm{~min}$. Data were gathered with Chemstation.

\section{Hatchability test}

This test was carried out to determine the effect of the essential oils from the leaves of Artemisia afra extracted through different methods on the hatchability of brine shrimp eggs. Twenty shrimp eggs were introduced into a $30-\mathrm{ml}$ capacity sterile petri-dish, each containing a freshly prepared mixture of the essential oil and sea water at a different concentration rate of 31.25 , $62.5,125,250,500$ and $1000 \mu \mathrm{g} / \mathrm{ml}$. A negative control sample consisting of $0.1 \%$ dimethyl sulphoxide (DMSO: $0.1 \mathrm{~mL}$ DMSO in $100 \mathrm{~mL}$ sea water) without the addition of oil was prepared. Control samples consisting of $0.1 \%$ dimethyl sulphoxide (DMSO: $0.1 \mathrm{~mL}$ DMSO in $100 \mathrm{~mL}$ seawater), seawater and chloramphenicol were prepared. The experiment was carried out in triplicate based on the procedure adopted by Kayode and Afolayan [11].

\section{Lethality test}

The test was conducted to ascertain the effect of essential oils from fresh and dried leaves of Artemisia afra on Artemia salina larvae. This study adopted the methods employed by Kayode and Afolayan [11]; Okoh and Afolayan [12] for determining the lethality of essential oils on Artemia salina. The Artemia salina eggs were sourced from Ocean Star International, USA. The eggs were hatched in sea water for $48 \mathrm{~h}$ at $28^{\circ} \mathrm{C}$ with constant illumination. The naupili (harvested A. salina) were attracted to one side of the vials with illumination. The stock solution of the essential oils from $A$. afra was prepared by dissolving $100 \mathrm{mg}$ of the essential oil in $1.0 \mathrm{ml}$ of DMSO. From the stock solution, $100 \mathrm{~mL}$ of different concentrations of $31.25,62.5,125,250$, 500 and $1000 \mu \mathrm{g} / \mathrm{mL}$ of the essential oils was prepared with natural seawater. Different Control samples without essential oil: $0.1 \%$ DMSO in sea water, sea water and chloramphenicol. The lethality experiments were carried out in triplicates for the essential oils studied.

\section{Statistical analysis}

Statistical analysis was done using one-way analysis of variance (ANOVA) followed by Duncan multiple range tests (DMRT), and by probit regression analysis of $\mathrm{LC}_{50}$ using SPSS. The data generated from ANOVA are presented as mean \pm SE. Significance level was set at $p<$ 0.05 .

\section{RESULTS}

\section{Dry weight}

The dry weight of the leaf after it was oven-dried was $34.07 \%$.

\section{Yield and physicochemical characteristics of A. afra leaf essential oil}

The yield in percentage and physicochemical characteristics of the essential oils from the leaf of $A$. afra extracted with hydrodistillation and solvent-free microwave extraction is depicted in Table 1.

Table 1: Some properties of essential oils of fresh and dried leaves of $A$. afra

\begin{tabular}{lcc}
\hline Mode of extraction & $\begin{array}{c}\text { Fresh leaf } \\
\text { (\%) }\end{array}$ & $\begin{array}{c}\text { Dried leaf } \\
\mathbf{( \% )}\end{array}$ \\
\hline Hydrodistillation (yield) & 1.02 & 0.84 \\
Solvent-free microwave & 0.97 & 0.73 \\
extraction (yield) & \multicolumn{2}{|c}{ Light yellow hue } \\
Colour & \multicolumn{2}{c}{ Resinous Aroma } \\
Scent & \multicolumn{2}{c}{ Strong } \\
Strength of aroma & \multicolumn{2}{c}{} \\
\hline
\end{tabular}

\section{Essential oil composition}

The composition of the essential oils analyzed through GCMS is depicted in Table 2. The Table showed that with the use of hydrodistillation method, 36 and 37 compounds were identified from fresh and dried leaves of $A$. afra respectively. On the other hand, 47 and 50 compounds were extracted from fresh and dried 
leaves of a. afra using solvent-free microwave extraction method.

\section{Effect of $A$. afra leaf essential oils on hatchability of Artemia salina}

The percentage hatchability of Artemia salina treated with varied concentration of essential oil in the different time range is illustrated in Figures 1-6. The percentage hatchability range from $10 \%$ after $12 \mathrm{~h}$ exposure at a concentration of $500 \mu \mathrm{g} / \mathrm{mL}$ to $83.33 \%$ after $72 \mathrm{~h}$ at a concentration of $31 \mu \mathrm{g} / \mathrm{mL}$. The figure shows the significant difference $(p<0.05)$ in the activities of the test oils on the hatchability success of Artemia salina. It also depicts the activities of chloramphenicol treated samples, natural seawater and $0.1 \%$ DMSO on the hatchability success of Artemia salina.

Effect of essential oils of $A$. afra on survival of Artemia salina

The survival assessment of Artemia salina treated with essential oils at different concentrations with different time of exposure is depicted in Figure 7 - Figure 12. The figures show that the mortality ranged from $13.33 \%$ following $12 \mathrm{~h}$ exposure at a concentration of 31 $\mu \mathrm{g} / \mathrm{mL}$ to $90 \%$ after $72 \mathrm{~h}$ exposure at a concentration of $1000 \mu \mathrm{g} / \mathrm{mL}$. This test shows the variation in the mortality activities of the test oils and individual samples treated with chloramphenicol, natural sea water and $0.1 \%$ DMSO respectively on Artemia salina.

Table 2: Essential oil constituents (monoterpenes hydrocarbons) of fresh and dried leaves of Artemisia afra obtained by hydrodistillation (HD) and solvent-free microwave (MC) methods

\begin{tabular}{|c|c|c|c|c|c|c|}
\hline S/no & Essential oil constituent & $\begin{array}{c}\text { Fresh Leaf } \\
\text { MC (\%) }\end{array}$ & $\begin{array}{c}\text { Dried Leaf } \\
\text { MC (\%) }\end{array}$ & $\begin{array}{c}\text { Fresh Leaf } \\
\text { HD (\%) }\end{array}$ & $\begin{array}{c}\text { Dried Leaf } \\
\text { HD (\%) }\end{array}$ & $\mathbf{K I}$ \\
\hline 1. & Santolina triene & 0.48 & & 0.06 & 0.38 & 926 \\
\hline 2. & $\alpha$ - Pinene & 0.10 & & 0.05 & & 936 \\
\hline 3. & $\alpha$-Thujene & & & & 0.10 & 936 \\
\hline 4. & Camphene & 1.73 & & & 1.57 & 947 \\
\hline 5. & Sabinene & 0.65 & 0.23 & 0.56 & 0.51 & 955 \\
\hline 6. & $\beta$ - Myrcene & 0.44 & 2.68 & 0.38 & 0.33 & 960 \\
\hline 7. & Yomogi Alcohol & 0.71 & 0.11 & 0.38 & 0.61 & 962 \\
\hline 8. & a- Phellandrene & 0.12 & 0.41 & 0.08 & 0.19 & 968 \\
\hline 9. & $(+)$-4-Carene & 0.32 & & 0.14 & 0.34 & 973 \\
\hline 10. & $\rho$ - Cymene & 1.54 & 1.45 & 0.88 & 1.66 & 976 \\
\hline 11. & Eucalyptol & 12.73 & 3.74 & 9.57 & 12.90 & 980 \\
\hline 12. & Artemisia Ketone & 4.24 & 0.99 & 3.29 & 2.90 & 989 \\
\hline 13. & Eugenol & 0.13 & & & & 1101 \\
\hline 14. & Thujone & 26.57 & 25.82 & 32.02 & 30.26 & 1012 \\
\hline 15. & Isothujol & 0.22 & & 0.33 & & 1022 \\
\hline 16. & Camphor & 13.26 & & 11.71 & 13.00 & 1029 \\
\hline 17. & 3-p-Menthene & & & 1.79 & & 1031 \\
\hline 18. & $(-)$ - Terpinen-4-ol & 1.91 & 0.7 & 1.45 & 1.70 & 1039 \\
\hline 19. & a- Thujenal & 0.28 & & 0.27 & & 1041 \\
\hline 20. & L-. $\alpha$ - Terpineol & 0.40 & 0.82 & 0.44 & 0.41 & 1043 \\
\hline 21. & Myrtenol & & & 0.72 & & 1045 \\
\hline 22. & Cis-Piperitol & 0.60 & 0.67 & 1.28 & 1.51 & 1045 \\
\hline 23. & Piperitol & 0.62 & 0.39 & & 0.72 & 1049 \\
\hline 24. & Cis-Verbenone & 0.27 & 2.76 & & & 1054 \\
\hline 25. & Cis-p-mentha-1 (7). 8- dien-2-ol & & & & 0.15 & 1056 \\
\hline 26. & 2- Carene & 0.83 & 0.40 & 0.86 & & 1062 \\
\hline 27. & (-)-Limonene & 0.08 & & & & 1098 \\
\hline 28. & Linalool & 2.07 & & & & 1178 \\
\hline 29. & Trans-Pinocamphone & & 2.22 & & & 1216 \\
\hline 30. & 3-tert-Butyphenol & & 2.47 & & & 1273 \\
\hline 31. & 3-Allylguaiacol & & 0.20 & 0.19 & 0.11 & 1362 \\
\hline
\end{tabular}

Table 3: Essential oil constituents (oxygenated monoterpenes) of fresh and dried leaves of Artemisia afra obtained by hydrodistillation (HD) and solvent-free microwave (MC) methods

\begin{tabular}{clccccc}
\hline S/No & $\begin{array}{l}\text { Essential oil } \\
\text { constituent }\end{array}$ & $\begin{array}{c}\text { Fresh Leaves } \\
\text { MC (\%) }\end{array}$ & $\begin{array}{c}\text { Dried Leaves } \\
\text { MC (\%) }\end{array}$ & $\begin{array}{c}\text { Fresh Leaves } \\
\text { HD (\%) }\end{array}$ & $\begin{array}{c}\text { Dried Leaves } \\
\text { HD (\%) }\end{array}$ & KI \\
\hline 1. & Borneal & 2.51 & 1.17 & 3.16 & 2.50 & 1036 \\
2. & Chamazulene & 0.06 & & & 0.06 & 1200 \\
3. & Phytol & 0.08 & & & 1232 \\
\hline
\end{tabular}


Table 4: Essential oil constituents (sequiterpene hydrocarbon) of fresh and dried leaves of Artemisia afra obtained by hydrodistillation (HD) and solvent-free microwave (MC) methods

\begin{tabular}{|c|c|c|c|c|c|c|}
\hline S/No & $\begin{array}{l}\text { Essential oil } \\
\text { constituent }\end{array}$ & $\begin{array}{c}\text { Fresh Leaf MC } \\
(\%)\end{array}$ & $\begin{array}{l}\text { Dried Leaf } \\
\text { MC (\%) }\end{array}$ & $\begin{array}{c}\text { Fresh Leaf } \\
\text { HD (\%) }\end{array}$ & $\begin{array}{c}\text { Dried Leaf } \\
\text { HD (\%) }\end{array}$ & KI \\
\hline 1. & Caryophyllene & 0.35 & 0.89 & 0.24 & 0.28 & 1104 \\
\hline 2. & $\beta$ - copaene & 0.05 & 0.06 & & 0.06 & 1106 \\
\hline 3. & Humulene & 0.07 & 0.07 & 0.07 & 0.08 & 1113 \\
\hline 4. & Y-Muurolene & 0.24 & & & & 1118 \\
\hline 5. & Germacerene D & 1.89 & & 1.96 & 1.67 & 1121 \\
\hline 6. & $\delta$ - Cadinene & 0.40 & 0.15 & 0.48 & 0.27 & 1130 \\
\hline 7. & Nerolidol & 0.14 & 0.05 & & 0.16 & 1137 \\
\hline 8. & Bicyclogermacrene & & & 0.82 & 0.89 & 1140 \\
\hline 9. & Spathulenol & 0.47 & 0.42 & 0.51 & 0.63 & 1147 \\
\hline 10. & Viridiflorol & 0.19 & & & 0.17 & 1152 \\
\hline 11. & Cadina - 1(2), 4 diene & & & 0.10 & 0.20 & 1159 \\
\hline 12. & Tau. -Muurolol & 1.28 & & & & 1163 \\
\hline 13. & a-Cadinol & 0.50 & 0.44 & 1.04 & 1.21 & 1166 \\
\hline 14. & a- Gurjunene & & & & 0.65 & 1170 \\
\hline 15. & a. - Copaene & & 0.23 & 0.47 & 0.26 & 1322 \\
\hline 16. & (-) -. B. Bourbonene & & 0.25 & & & 1328 \\
\hline 17. & Alloaromadendrene & & 0.05 & & 0.06 & 1372 \\
\hline 18. & $\beta$-Cubebene & & 0.87 & & & 1382 \\
\hline 19. & $\beta$-Gurjunene & & 0.13 & & & 1390 \\
\hline 20. & Cubenol & & 0.11 & & & 1400 \\
\hline 21. & Caryophyllene oxide & & 0.60 & & & 1438 \\
\hline 22. & Ledene oxide- (II) & & 0.09 & & & 1450 \\
\hline 23. & Y-Selinene & & 0.10 & & & 1476 \\
\hline 24. & Shyobunone & & 0.06 & & & 1547 \\
\hline
\end{tabular}

Table 5: Essential oil constituents (esters) of fresh and dried leaves of Artemisia afra obtained by hydrodistillation (HD) and solvent-free microwave (MC) methods

\begin{tabular}{|c|c|c|c|c|c|c|}
\hline S/No & Essential oil constituent & $\begin{array}{l}\text { Fresh Leaves } \\
\text { MC (\%) }\end{array}$ & $\begin{array}{l}\text { Dried Leaves } \\
\text { MC (\%) }\end{array}$ & $\begin{array}{c}\text { Fresh Leaves } \\
\text { HD (\%) }\end{array}$ & $\begin{array}{c}\text { Dried Leaves } \\
\text { HD (\%) }\end{array}$ & $\mathbf{K I}$ \\
\hline 1. & $\begin{array}{l}\text { Pentanoic acid, 2- methylbutyl } \\
\text { ester }\end{array}$ & 0.16 & & & & 1007 \\
\hline 2. & $\begin{array}{l}\text { Butanoic acid, } 2 \text { methyl-, 2- } \\
\text { methylbutyl ester }\end{array}$ & & & & 0.20 & 1007 \\
\hline 3. & $\begin{array}{l}\text { 3- Methyl-2-butenoic acid, oct- } \\
\text { 3-en-yl ester }\end{array}$ & 1.81 & & & & 1025 \\
\hline 4. & $\begin{array}{l}\text { Acetic acid, 1, 7, 7- trimethyl- } \\
\text { bicyclo [2.2.1] hept-2-yl ester }\end{array}$ & & & 0.97 & & 1087 \\
\hline 5. & $\begin{array}{l}\text { 3-Methylbut-2-enoic acid, 4- } \\
\text { nitrophenyl ester }\end{array}$ & & 0.14 & & & 1616 \\
\hline 6. & $\begin{array}{l}\text { 5- Isopropyl-2-methylphenyl 2- } \\
\text { methylbut-2-enoate }\end{array}$ & & 0.15 & & & 1639 \\
\hline 7. & $\begin{array}{l}\text { 3- Methylbut-2-enoic acid, 3, } \\
\text { 4-dichlorophenyl ester }\end{array}$ & & 0.53 & & & 1641 \\
\hline 8. & $\begin{array}{l}\text { 3-Methyl-2-butenoic acid, 2- } \\
\text { methyl oct-5-yn-4-yl ester }\end{array}$ & & 0.08 & & & 1660 \\
\hline 9. & $\begin{array}{l}\text { 3- Methybut-2-enoic acid, 4- } \\
\text { isopropylphenyl ester }\end{array}$ & & 0.62 & & & 1690 \\
\hline 10. & $\begin{array}{l}\text { (E)-2-Isopropyl -5- } \\
\text { methylphenyl 2-methylbut-2- } \\
\text { enoate }\end{array}$ & & 0.62 & & & 1700 \\
\hline 11. & $\begin{array}{l}\text { 3- Methylbut-2-enoic acid, oct- } \\
\text { 3-en-2-yl ester }\end{array}$ & & 1.25 & & & 1709 \\
\hline 12. & $\begin{array}{l}\text { 3-Methylbut-2-enoic acid, } 2,3 \text {, } \\
\text { 4, 6- tetrachlorophenyl ester }\end{array}$ & & 0.23 & & & 1734 \\
\hline 13. & $\begin{array}{l}\text { 3-Methyl-2-butenoic acid, } \\
\text { pent-2-en-4-ynyl ester }\end{array}$ & & 0.13 & & & 1790 \\
\hline 14. & $\begin{array}{l}\text { 3- Methyl-2-butenoic acid, } \\
\text { cyclobutyl ester }\end{array}$ & & 0.14 & & & 1977 \\
\hline 15. & $\begin{array}{l}\text { Cyclohexane, (2-nitro-2- } \\
\text { propenyl) }\end{array}$ & & 0.46 & & & 2109 \\
\hline
\end{tabular}




\section{Lethality of the essential oils on Artemia salina}

Table 2 shows the concentration required to kill half of the population of test Artemia salina. The $\mathrm{LC}_{50}$ of fresh and dried leaves extracted through hydrodistillation method is $206.97 \mu \mathrm{g} / \mathrm{mL}$ and $406.48 \mu \mathrm{g} / \mathrm{mL}$ respectively. The $\mathrm{LC}_{50}$ of fresh and dried leaves extracted through SFME are 277.18 and $669.30 \mu \mathrm{g} / \mathrm{ml}$ respectively. The study also takes into cognizance of the $\mathrm{LC}_{50}$ of a control sample: Chloramphenicol, which has an $\mathrm{LC}_{50}$ of $283.26 \mu \mathrm{g} / \mathrm{mL}$.

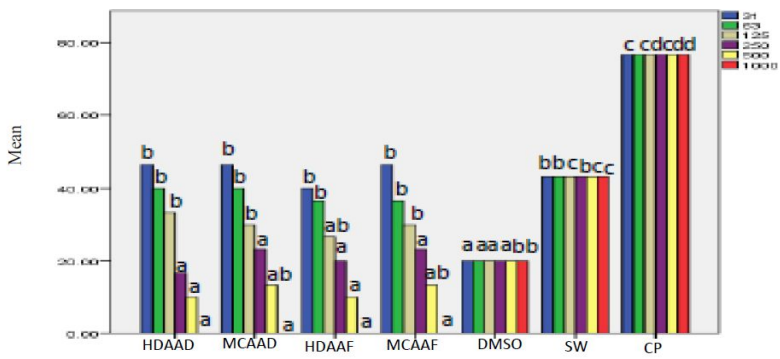

Figure 1: Hatchability after $12 \mathrm{~h}$ exposure

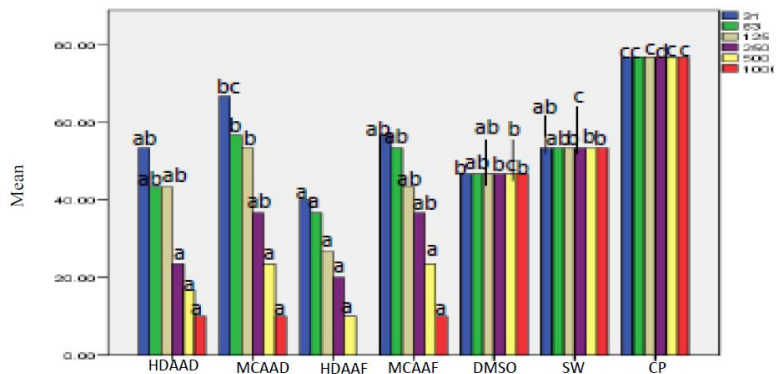

Figure 2: Hatchability after $24 \mathrm{~h}$ exposure

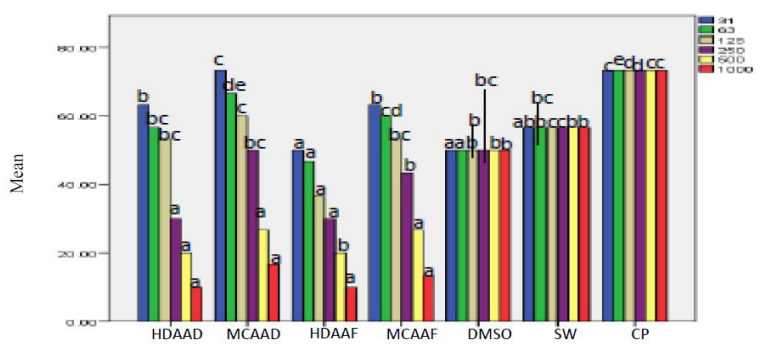

Figure 3: Hatchability after $36 \mathrm{~h}$ exposure

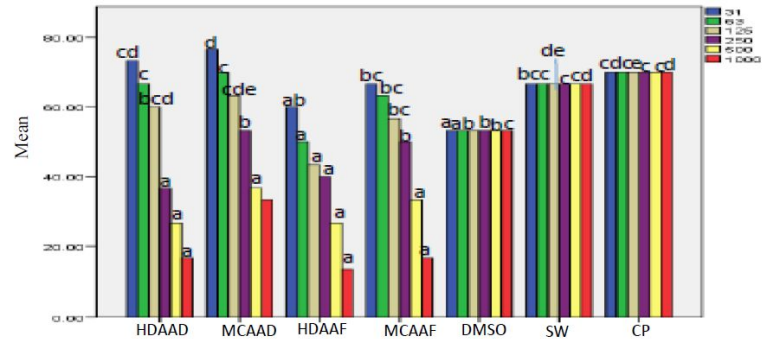

Figure 4: Hatchability after $48 \mathrm{~h}$ exposure

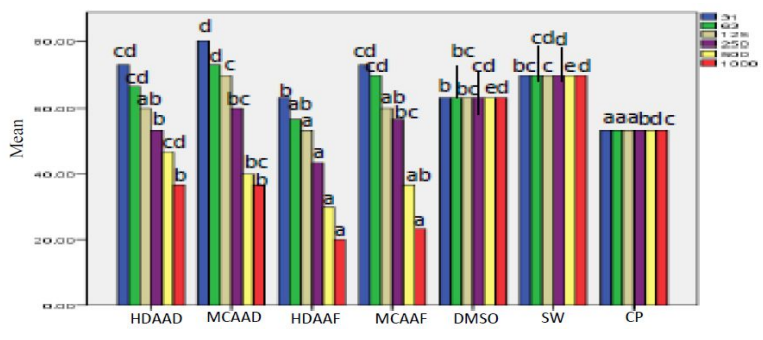

Figure 5: Hatchability after $60 \mathrm{~h}$ exposure

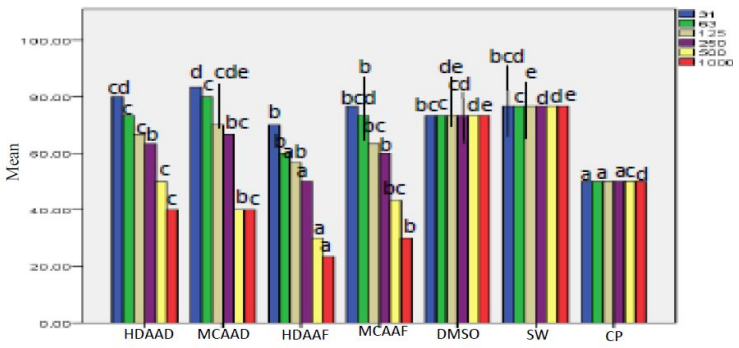

Figure 6: Hatchability after $72 \mathrm{~h}$ exposure

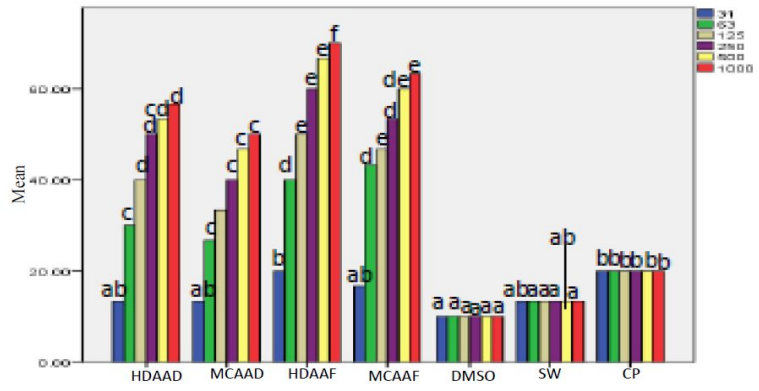

Figure 7: Lethality after $12 \mathrm{~h}$ exposure

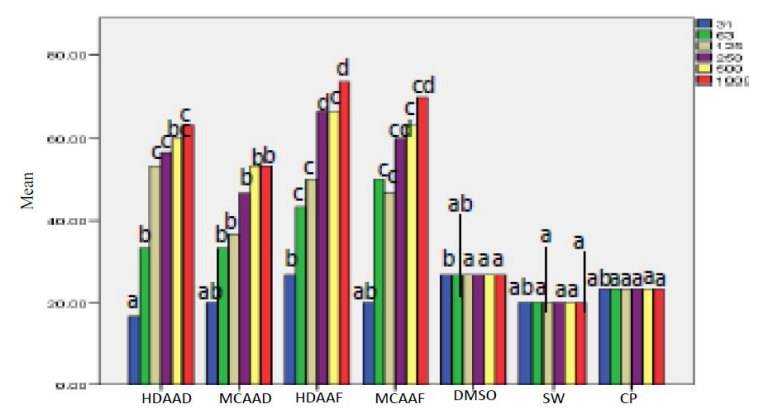

Figure 8: Lethality after $24 \mathrm{~h}$ exposure

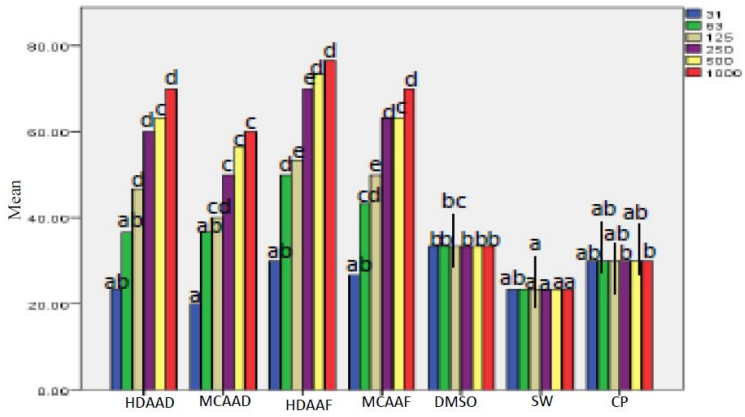

Figure 9: Lethality after $36 \mathrm{~h}$ exposure 


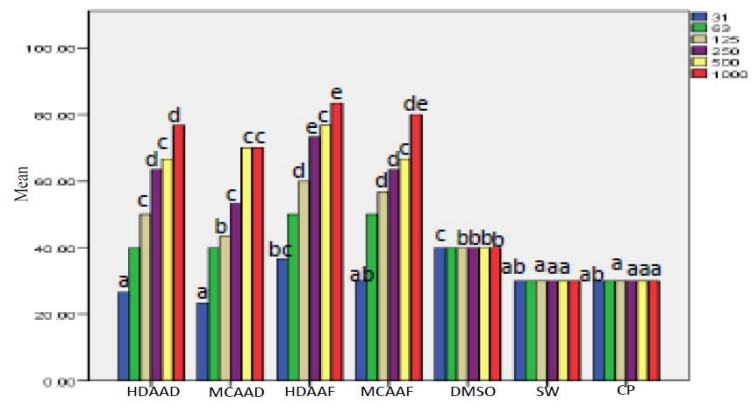

Figure 10: Lethality after $48 \mathrm{~h}$ exposure

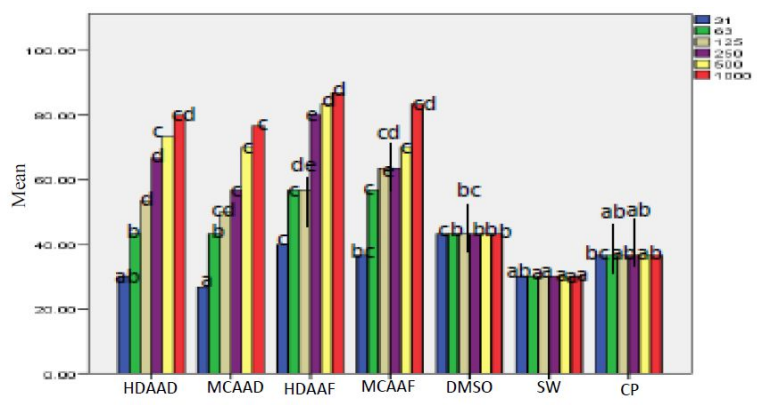

Figure 11: Lethality after $60 \mathrm{~h}$ exposure

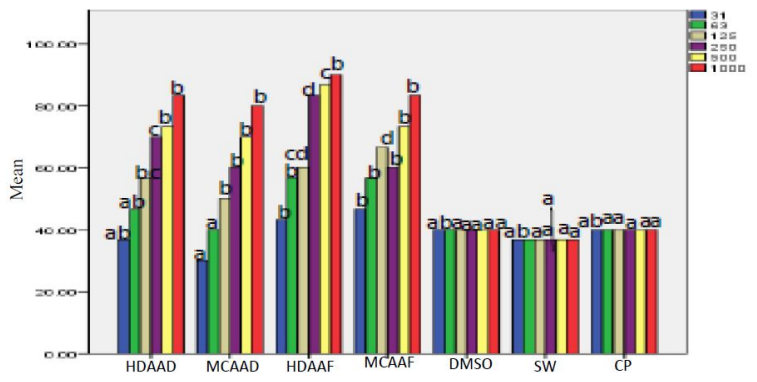

Figure 12: Lethality after $72 \mathrm{~h}$ exposure

\section{DISCUSSION}

The use of Artemisia afra (Jacq) ex Wild for medicinal purposes has been documented in African ethnopharmacology [19]. The plant alone or in combination has been acknowledged for the treatment of influenza, measles, fever, lung inflammations and food preservation $[5,19]$.
The physicochemical properties of the studied oils were similar to previous works by Liu et al [19]. The loss in weight of the leaves of $A$. afra after drying in the oven indicated that there was moisture loss and this was also reflected in the yield of the essential oil from the dried leaves of the plant (dry weight of the leaf was $34.07 \%$ ). The leaf was oven-dried at $30^{\circ} \mathrm{C}$, which enable the leaf to still hold its quality compared to what was obtained in fresh leaves. This falls within the assertion raised by Alakali et al [20] that drying of plant samples above $50{ }^{\circ} \mathrm{C}$ can affect the quality of the sample. The assertion showed that $A$. afra dried at $30^{\circ} \mathrm{C}$ would still maintain its quality. The reduced yield of essential oil from the dried leaves of $A$. afra supported what was observed by Kayode and Afolayan [11] that the dried seed of Moringa oleifera had lower yield, compared to the yield from the test fresh seed of Moringa oleifera.

This study was able to deduce that the yield of essential oils from the fresh leaves using SFME and $\mathrm{HD}$ was higher than the yield of dried leaves using SFME and HD. The deduction noticed in this study is at variance with the report by Silva et al [21], where the dried leaves of Eucalyptus cinera had a higher yield than the fresh ones. The yield of essential oils from the leaves of $A$. afra was higher when using hydrodistillation method than SFME methods. This corroborates the work of Kayode and Afolayan [11], where they posited that the seed of Moringa oleifera had higher essential oils with HD than SFME. Lucchesi et al [14] confirmed that there was higher yield following extraction with HD when compared with SFME. Surprisingly, they observed that the yield from HD was not quite significant when compared to SFME in terms of heating time. It took the HD (up to $4.5 \mathrm{~h}$ ) and SFME (about $30 \mathrm{~min}$ ) to achieve the same purpose and this couldn't explain the differences in yield.

Table 3: Lethality $\left(\mathrm{LC}_{50}\right)$ of test oils extracted from A. afra on Artemia salina

\begin{tabular}{lccccc}
\hline Treatment & $\mathbf{L C}_{\mathbf{5 0}}(\boldsymbol{\mu} \mathbf{g} / \mathbf{m l})$ & Regression Equation & $\mathbf{R}^{\mathbf{2}}(\mathbf{\%})$ & $\boldsymbol{P}$ - value & Chi-square \\
\hline HDAAD & 406.48 & $\mathrm{Y}=0.0014 \mathrm{X}+-1$ & 47.0 & 0.00 & 35.85 \\
HDAAF & 206.97 & $\mathrm{Y}=0.0015 X+-0.9$ & 63.0 & 0.00 & 23.12 \\
MCAAD & 669.30 & $\mathrm{Y}=0.0012 \mathrm{X}+-1$ & 59.2 & 0.06 & 14.38 \\
MCAAF & 277.18 & $\mathrm{Y}=0.0015 X+-0.9$ & 54.2 & 0.00 & 28.15 \\
CP & 283.26 & $\mathrm{Y}=0.0032 X+0.9$ & 77.2 & 0.15 & 3.76 \\
\hline
\end{tabular}

$\mathrm{R}^{2}=$ coefficient of determination of regression equation, $p$ values indicate the level of significance of the regression equation; values less than 0.05 are significant and those less than 0.05 are not significant at $5 \%$ level of probability. HDAAD: Dried leaves of $A$. afra extracted through Hydrodistillation Method; HDAAF: Fresh leaves of $A$. afra extracted through Hydrodistillation Method; MCAAD: Dried leaves of $A$. afra extracted through Solvent Free Microwave Extraction Method; MCAAF: Fresh leaves of $A$. afra extracted through Solvent Free Microwave Extraction Method 
The phytoconstituents identified from the fresh and dried leaves of $A$. afra through $\mathrm{HD}$ and SFME were 73 compounds. Liu et al [19] documented the presence of more than 130 compounds in the oils from $A$. afra. It can be deduced from Table 2 to Table5 that there were more compounds from the oil of dried leaf samples of $A$. afra processed through hydrodistillation and SFME methods. This deduction corroborates the previous observation raised by Asekun et al [22] that more compounds were present in essential oils extracted from the dried leaves of Mentha longiflora L. compared to the fresh leaves of $M$. longiflora. There is the dominance of monoterpenoids and considerable amounts of sesquipterpenoids such as: chamazulene, bicyclogermacrene, caryophyllene oxide, caryophyllene, humulene and $\beta$-copaene, in the oils extracted across the dried and fresh leaves, supporting an earlier work by Asekun et al [5].

The presence of $\beta$ - myrcene, $\alpha$ - phellandrene, $\rho$-cymene, eucalyptol, Artemia ketone, thujone and some other compounds in all the oils analyzed showed that the methods of extraction or state of the plant samples doesn't significantly affect the presence of some compounds in the essential oils [11,23]. The lesser yield observed in the oils from dried leaves of $A$. afra extracted with $\mathrm{HD}$ and SFME could be due to drying activities prior to extraction as has been suggested by Rahimmalek and Goli [24]. They asserted that drying before distillation might be responsible for the reduced yield of essential oils from the leaves of Thymys daenensis.

Thujone, camphor and eucalyptol were compounds were compounds identified with high percentage composition. They have been documented in the literature to possess antimicrobial, food preservation and ethnopharmacological activities [25,26]. The presence of Cis-verbenone, shyobunone and other compounds in the oils extracted through SFME method might be due to the reduction in thermal and hydrolytic effect when compared with hydrodistillation that that uses a large quantity of water, time and energy [14].

The hatchability results obtained showed that the test oils had insignificant inhibition at a lower concentration. The inhibition of $A$. salina was more pronounced with essential oils extracted from fresh leaves of $A$. afra. Hai-bin et al [27] established the anti-insecticidal activity of essential oils from Artemisia lavandulaefolia and some of the compounds noted in their work are reported in this present study.
The status of the leaf (fresh or dry) and method of extraction determined the mortality rate of essential oil on Artemia salina. The mortality assessment of $A$. salina can be summarized as follows: fresh leaf extracted through HD had the high mortality rate, followed by fresh leaf through SFME, dried leaf through $H D$ and dried leaf through SFME.

The $\mathrm{LC}_{50}$ obtained at $24 \mathrm{~h}$ were 206.97, 406.48, 277.16 and $669.30 \mu \mathrm{g} / \mathrm{ml}$ for fresh leaf (HD), dried leaf (HD), fresh leaf (SFME) and dried leaf (SFME), respectively. The $\mathrm{LC}_{50}$ of the test oils showed that they are moderately toxic on $A$. salina. The toxicity status of the test oils was deduced from Clarkson's toxicity index. Clarkson's toxicity index described toxicity status as follows: non-toxic ( $\left.\mathrm{LC}_{50}>1000 \mu \mathrm{g} / \mathrm{mL}\right)$, low toxic $\left(\mathrm{LC}_{50}\right.$ of $\left.500-1000 \mu \mathrm{g} / \mathrm{mL}\right)$, medium toxic $(100-500 \mu \mathrm{g} / \mathrm{mL})$ and toxic $(0-100 \mu \mathrm{g} / \mathrm{mL})$.

The toxicity of the essential oils obtained from $A$. afra are moderate when compared to the values obtained for other essential oils of the genus Artemisia. Mojarrab et al [28] reported $\mathrm{LC}_{50}$ values of 49.98 and $56.94 \mu \mathrm{g} / \mathrm{mL}$ for $A$. incana and $A$. armeniaca, which are less than what was obtained in this study. They opined that the presence of thujone might have contributed to the toxicity of the essential oils, as it has been reported to cause nausea, vomiting, insomnia, restlessness, vertigo and tremors.

\section{CONCLUSION}

Essential oils are generally regarded as safe for humans. The findings of this study established hydrodistillation method as a better method of extraction of essential oil than SFME method, as well as the presence of various chemical compounds in Artemisia afra leaves. Furthermore, the toxic activity of the oils against Artemia salina suggests that they may possess anticancer properties but this needs to be further investigated.

\section{DECLARATIONS}

\section{Acknowledgement}

We greatly appreciate the National Research Foundation (NRF) and the Govan Mbeki Research and Development Centre (GMRDC) of the University of Fort Hare, South Africa, for funding this project. The authors will also like to appreciate the University of Lagos, Nigeria for releasing $\mathrm{Dr}$ OO Adeogun to access postdoctoral fellowship through GMRDC at the University of Fort Hare. 


\section{Conflict of interest}

No conflict of interest is associated with this work.

\section{Contribution of authors}

The authors declare that the authors listed in this manuscript did this work and they would be responsible for all liabilities pertaining to claims relating to the content of this article.

\section{REFERENCES}

1. Sunmonu TO, Afolayan AJ. Evaluation of Antidiabetic Activity and Associated Toxicity of Artemisia afra aqueous extract in Wistar rats. Evid Based Complement Alternat Med 2013; Article ID 929074: 1- 8.

2. Mukinda, JT, Syce JA. Acute and chronic toxicity of the aqueous extract of Artemisia afra in rodents. $J$ Ethnopharmacol 2017; 112: 138-144.

3. IwU MM. Handbook of African medicinal plants. USA: CRC Press; 2014. P. 145-146.

4. Van Wyk BE. A broad review of commercially important southern African medicinal plants. J. Ethnopharmacol. 2008; 119: 342-355

5. Asekun OT, Grierson DS, Afolayan AJ. Variations in the quality and yield of the essential oil from Artemisia afra using different drying methods. J. Essent Oil Res.; 10(1): 5-9.

6. Graven EH, Webber L, Venter M., Gardner JB. The development of Artemisia afra (Jacq) as a new essential oil crop. J. Essent Oil Research 1990; 2: 215-220.

7. Graven E, Deans S, Mavi S, Gundidza MG, Svoboda KP. Antimicrobial and antioxidative properties of the volatile (essential) oil of Artemisia afra. Flavour Fragr J. 1992; 7: 121-123.

8. Mangena T, Muyima NYO. Comparative evaluation of the antimicrobial activities of essential oils of Artemisia afra, Pteronia incana and Rosmarius officialis on selected bacteria and yeast strains. Lett Appl Microbiol. 1999; 28(4): 291- 296.

9. Oyedeji AO, Afolayan AJ, Hutchings A. Compositional variation of the essential oils of Artemisia afra Jacq. From three provinces in South Africa-a case study of its safety. Nat Prod Commun. 2009; 4(6): 849-852.

10. Viljoen $A M$, Subramoney $S$, van Vuuren SF, Baser KHC, Demirci $B$. The composition, geographical variation and antimicrobial activity of Lippia javanica (Verbenaceae) leaf essential oils. J Ethnopharmacol 2005; 96: 271-277.

11. Kayode RMO, Afolayan AJ. Cytotoxicity and effect of extraction methods on the chemical composition of essential oils of Moringa oleifera seeds. J. Zhejiang Univ-Sci B (Biomed and Biotechnol) 2015; 16(8): 680689.

12. Okoh OO, Afolayan AJ. The effects of hydrodistillation and solvent free microwave extraction methods on the chemical composition and toxicity of essential oils from the leaves of Mentha longiflora L. subsp. capensis. Afr J Pharm Pharmacol 2011; 5(22): 2474-2478.

13. Lucchesi ME, Chemat F, Smadja J. An original solvent free microwave extraction of essential oils from spices. Flavour Fragr. J 2004a; 19 (2): 134-138.

14. Lucchesi ME, Chemat F, Smadja J. Solvent-free microwave extraction of essential oil from aromatic herbs: comparison with conventional hydrodistillation. $J$ Chromatogr A 2004b; 1043(2):323-327.

15. Bayramoglu B, Sahin S, Sumnu G. Solvent-free microwave extraction of essential oil from oregano. $J$ Food Eng. 2008; 88: 535-540.

16. Meyer BN, Ferrigni NR, Putnam JE, Jacobsen LB, Nichols DE, McLaughlin JL. Brine Shrimp: A convenient general bioassay for active plant constituents. Planta Medica 1982; 45: 31-34.

17. Adeogun O, Adekunle A, Ashafa A. Chemical composition, lethality and antifungal activities of the extracts of leaf of Thaumatococcus daniellii against foodborne fungi. Beni-Seuf Univ J Appl Sci 2016; 5:356368.

18. Okoh OO, Sadimenko AP, Afolayan AJ. Comparative evaluation of the antibacterial activities of the essential oils of Rosmarinus officinalis $L$. obtained by hydrodistillation and solvent free microwave extraction methods. Food Chem 2010; 120: 308-312.

19. Liu NQ, Van der Kooy F, Verpoorte R. Artemisia afra: $A$ potential flagship for African medicinal plants? S Afri J Bot 2009; 75: 185-195.

20. Alakali JS, Kucha CT, Rabiu IA. Effect of drying temperature on the nutritional quality of Moringa oleifera leaves. Afr J Sci 2015; 9(7): 395-399.

21. Silva SM, Abe SM, Murakami FS, Frensch G, Marquis $F A$, Nakashima $T$ (2011). Essential oils from different plant parts of Eucalyptus cinera F. Muell. Ex Benth (Myrtaceae) as a source of 1, 8-Cineole and their bioactivities. Pharm 4: 1535-1550.

22. Asekun OT, Grierson DS, Afolayan AJ. Effect of drying methods on the quality and quantity of the essential oil of Mentha longiflora L. subsp. Capensis. Food Chem 2007; 101: 995-998.

23. Rahimmalek M, Goli SA. Evaluation of six drying treatments with respect to essential oil yield, composition and colour characteristics of Thymys daenensis subsp. daenensis: Calek leaves. Ind Crops Prod; 42: 613-619.

24. Chagonda LS, Makanda C, Chalchat J. The essential oil of cultivated Artemisia afra (Jacq.) from Zimbabwe. Flavour Fragr J 1999; 14: 140-142.

25. Vagionas K, Graikou K, Chinou IB, Runyoro D, Ngassapa $O$. Chemical analysis and antimicrobial activity of essential oils from the aromatic plants Artemisia afra Jacq. and Leonotis ocymifolia (Burm. F.) Iwarsson var. raineriana (Vision 1) Iwarsson growing in Tanzania. $J$ Essent Oil Res 2007; 19: 395-400.

26. Worku T. Major constituents of Artemisia afra oil. J.Essent Oil Res 1996; 7: 355-357. 
Adeogun et al

27. Hai-bin $Y$, Li-na S, Chu-yan $W$, Bing-Zhong $R$. Comparison of constituents and insecticidal activities of essential oil from Artemisia lavandulaefolia by steam distillation and supercritical $\mathrm{CO} 2$ fluid extraction. Chem Res Chin Univ 2010; 26(8): 888-892.
28. Mojarrab M, Delazar A, Esnaashi S, Afshar FH. Chemical composition and general toxicity of essential oils extracted from the aerial parts of Artemisia armeniaca Lam. and Artemisia incana (L.) Druce growing in Iran. Res Pharm Sci 2013; 8(1): 65-69. 